\title{
MODELING AND SIMULATION OF GRID-CONNECTED PHOTOVOLTAIC DISTRIBUTED GENERATION SYSTEM
}

\author{
M.MAKHLOUF ${ }^{\mathbf{1}}$, F.MESSAI ${ }^{1}$, H.BENALLA ${ }^{\mathbf{1}}$ \\ ${ }^{1}$ Department of Electrical Engineering, Faculty of Engineering Sciences, Mentouri University Route d'Ain \\ El Bey, Constantine, Algeria,

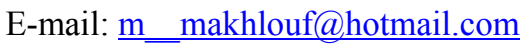

\begin{abstract}
Compared to the traditional energy resources, photovoltaic (PV) system that uses the solar energy to produce electricity considered as one of renewable energies has a great potential and developing increasingly fast compared to its counterparts of renewable energies. Such systems can be either stand-alone or connected to utility grid. However, the disadvantage is that PV generation depended on weather conditions. Thus there is also a need for developing control techniques for three phase grid connected PV systems including a method for DC link voltage control that stabilizes the voltage at the inverter input to insure a continuous flow of energy exchange between the grid and the PV system. An LC filter also is necessary to filter the output current and voltage from the harmonics and protect the grid from their destructive effect. This paper presents detailed modeling of the grid-connected photovoltaic generation system components, in Simulink / MATLAB software. Simulation results presented here validate the component models and the chosen control schemes.
\end{abstract}

Keywords: Grid Connected PV Systems, DC-DC Converter, PWM Inverter, MPPT, PI Controller.

\section{INTRODUCTION}

The increasing of the world energy demand, due to the modern industrial society and population growth, is motivating a lot of investments in alternative energy solutions, in order to improve energy efficiency and power quality issues. The use of photovoltaic energy is considered to be a primary resource, because there are several countries located in tropical and temperate regions, where the direct solar density may reach up to $1000 \mathrm{~W} / \mathrm{m}$.

At present, photovoltaic (PV) generation is assuming increased importance as a renewable energy sources application because of distinctive advantages such as simplicity of allocation, high dependability, absence of fuel cost, low maintenance and lack of noise and wear due to the absence of moving parts.
The cell conversion ranges vary from $12 \%$ of efficiency up to a maximum of $29 \%$ for very expensive units [1]. In spite of those facts, there has been a trend in price decreasing for modern power electronics systems and photovoltaic cells, indicating good promises for new installations.

However, the disadvantage is that photovoltaic generation is intermittent, depending upon weather conditions. Thus, the MPPT makes the PV system providing its maximum power and that energy storage element is necessary to help get stable and reliable power from PV system for both loads and utility grid, and thus improve both steady and dynamic behaviors of the whole generation system. In this paper we have studied a grid-connected photovoltaic generation system which is composed of PV array, power electronic converters, filter, controllers, local loads and utility grid as shown in figure 1. 


\section{Journal of Theoretical and Applied Information Technology \\ $30^{\text {th }}$ November 2012. Vol. 45 No. 2}

(C) 2005 - 2012 JATIT \& LLS. All rights reserved.

जคิTี

ISSN: 1992-8645

www.jatit.org

E-ISSN: 1817-3195

The paper discusses the detailed modeling of the whole system. PV array is connected to the utility grid by a boost converter to optimize the PV output and $\mathrm{DC} / \mathrm{AC}$ inverter to convert the DC output voltage of the solar modules into the AC system. The DC input of the inverter must be constant and it is controlled by the use of a PI control circuit. An LC filter has been introduced to insure a clean current injection to the grid.The proposed model of the entire components and control system are all simulated in Matlab/Simulink Software. Two different cases are simulated steady and transient states, and all simulation results have verified the validity of models and effectiveness of control methods.

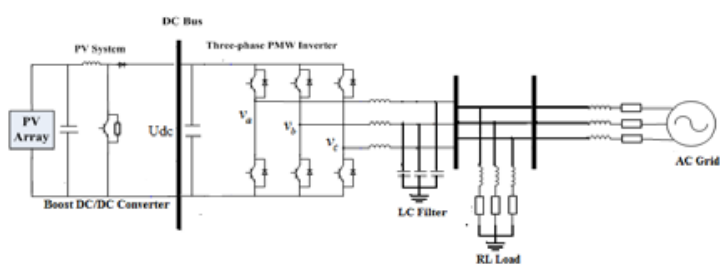

Fig. 1: Configuration Of The Grid-Connected Photovoltaic Generation System

\section{MODELING THE PV ARRAY}

The direct conversion of the solar energy into electrical power is obtained by solar cells. A PVG is composed by many strings of solar cells in series, connected in parallel, in order to provide the desired values of output voltage and current. Fig. 2 shows the equivalent circuit of a PVG, from which non linear $\mathrm{I}-\mathrm{V}$ characteristic can be deduced.

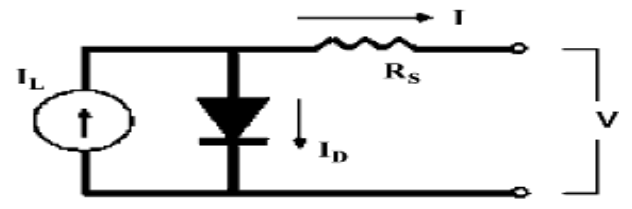

Fig. 2:Solar-Cell Equivalent Circuit.

The cells are connected in series and in parallel combinations in order to form an array of the desired voltage and power levels.

Applying Kirchoff's law of current, the terminal current of the cell is:

$I=I_{L}-I_{D}$
The light current is related to irradiance and temperature and the light current measured at some reference conditions:

$I_{L}=\left(\frac{G}{G_{R E F}}\right)\left(I_{L, R E F}+\mu_{I S C}\left(T_{C}-T_{C, R E F}\right)\right)$

Where

$\mathrm{I}_{\mathrm{L}, \mathrm{REF}}=$ Light current at reference conditions $[\mathrm{A}]$.

$\mathrm{G}, \mathrm{G}_{\mathrm{REF}}=$ Irradiance, actual and at reference condition $\left[\mathrm{W} / \mathrm{m}^{2}\right]$.

$\mathrm{T}, \mathrm{T}_{\mathrm{C}, \mathrm{REF}}=$ Cell temperature, actual and at reference condition $\left[{ }^{\circ} \mathrm{K}\right]$.

$\mu_{\mathrm{ISC}}=$ Manufacturer supplied temperature coefficient of short circuit current $\left[\mathrm{A} /{ }^{\circ} \mathrm{K}\right]$.

The diode current is given by Shockley equation:

$I D=I_{0}\left[\exp \left(\frac{q\left(V+I R_{S}\right)}{\gamma k T_{c}}\right)-1\right]$

Where:

$\mathrm{V}=$ terminal voltage $[\mathrm{V}], \mathrm{I}=$ reverse saturation current [Amps], $\gamma=$ shape factor.

$\mathrm{R}_{\mathrm{s}}=$ series resistance $[\Omega]$, $\mathrm{q}=$ electron charge $1.602 .10^{-19} \mathrm{~K}=$ Boltzmann constant $=1.381 .10^{-23}$ $\mathrm{J} / \mathrm{K}$.

The reverse saturation current is:

$I_{0}=D T_{c}^{3} \exp \left(\frac{-q \varepsilon_{G}}{A k T_{c}}\right)$

Where:

$\mathrm{D}=$ diode diffusion factor, $\varepsilon_{G}=$ material band gap

energy (1.12 eV for $\mathrm{Si}, 1.35 \mathrm{eV}$ for GaGs)

$\mathrm{A}=$ completion factor

The reverse saturation current is actually computed by taking the ratio of equation (4) at two different cell temperatures, thereby eliminating $\mathrm{D}$, similar to the determination of $\mathrm{I}_{\mathrm{L}}, \mathrm{I}_{0}$ is related to the temperature and the saturation current estimated at some reference conditions:

$I_{0}=I_{0, R E F}\left(\frac{T_{C}}{T_{C, R E F}}\right)^{3} \exp \left[\left(\frac{q \varepsilon_{G}}{k A}\right)\left(\frac{1}{T_{C, R E F}}-\frac{1}{T_{C}}\right)\right]$

And thus the I-V characteristic is described by:

$I=I_{L}-I_{0}\left[\exp \left(\frac{q\left(V+I R_{s}\right)}{\gamma k T_{c}}\right)-1\right]$

The shape factor $\gamma$ is a measure of cell temperature and is related to the completion factor 


\section{Journal of Theoretical and Applied Information Technology \\ $30^{\text {th }}$ November 2012. Vol. 45 No.2}

(C) 2005 - 2012 JATIT \& LLS. All rights reserved

ISSN: 1992-8645

www.jatit.org

E-ISSN: 1817-3195

as

$\gamma=A \cdot N C S \cdot N S$

$N C S$ is the number of cells connected in series per module. A module is defined as an array of cells, usually encapsulated for protection, as it is supplied by manufacturer; $N S$ is the number of modules connected in series of the entire array. While $\mathrm{R}_{\mathrm{s}}$ and $\gamma$ are assumed to be constant, $\mathrm{I}_{\mathrm{L}}$ is a function of irradiance and cell temperature and $\mathrm{I}_{0}$ is a function of temperature only. The cell temperature can be determined from the ambient temperature and with the help of some standard test information. In [2] the way to Evaluate these parameters based on the four parameters model proposed by Townsend (1989) [3], Eckstein (1990) [4] and Fry, Bryan (1998) [5] to be the most précised model that good produced the I-V characteristics.

Now only the four parameters $\mathrm{I}_{\mathrm{L}}, \mathrm{I}_{\mathrm{o}}$, Rs and $\gamma$ need to be evaluated, a method to calculate these parameters has been developed by Eckstein [4]. Since there are four unknown parameters, four conditions of the current $\mathrm{I}$ and the voltage $\mathrm{V}$ are needed. Generally, available manufacturer's information are set at three points at the reference conditions, $\left(\mathrm{G}=1000 \mathrm{~W} / \mathrm{m}^{2}, \mathrm{~T}=25^{\circ} \mathrm{C}\right)$, the voltage at open circuit $\mathrm{V}_{\text {oc,ref, }}$ the current at short circuit $\mathrm{I}_{\mathrm{sc}}$, ref and the voltage and current at maximum power $\mathrm{V}_{\mathrm{mp}}$,

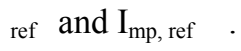

The 4th condition comes from the knowledge of the temperature coefficients at short circuit $\mu_{\mathrm{I}_{\mathrm{SC}}}$ and at open circuit $\mu_{\mathrm{V}_{0 \mathrm{C}}}$.

$I_{M P, R E F}=I_{S C, R E F}-I_{O, R E F} \times$

$\left(\operatorname{expV} \mathrm{t} \cdot\left(V_{M P R E F}+I_{M P}, R E F \cdot R_{S}\right)\right)$

$0=I_{S C}, R E F-I_{O}, R E F \cdot \exp \left(\mathrm{v}_{\mathrm{t}} \cdot V_{O C}, R E F\right)$

$I_{L, R E F} \approx I_{S C, R E F}$

Substituting equation (7) into equation (9) and solving for $\gamma$ and $I_{0, R E F}$ gives

$I_{0, R E F}=I_{S C, R E F} \cdot \exp -\left(\mathrm{V}_{\mathrm{t}} \cdot V_{O C, R E F}\right)$
$\gamma_{R E F}=\frac{q \cdot\left(V_{M P, R E F}+R_{S} \cdot I_{M P, R E F}-V_{O C}, R E F\right)}{K \cdot T_{C, R E F} \cdot \ln \left(1-\frac{I_{M P, R E F}}{I_{S C, R E F}}\right)}$

$(12)$

The indices $O C, S C, M P$ and REF refer to the open circuit, the short circuit, the maximum power and the reference condition respectively.

The cell's parameters change with the solar radiation $\mathrm{G}\left(\mathrm{W} / \mathrm{m}^{2}\right)$ and ambient temperature $\mathrm{T}\left({ }^{\circ} \mathrm{K}\right)$ and they can be estimated by the following relations:

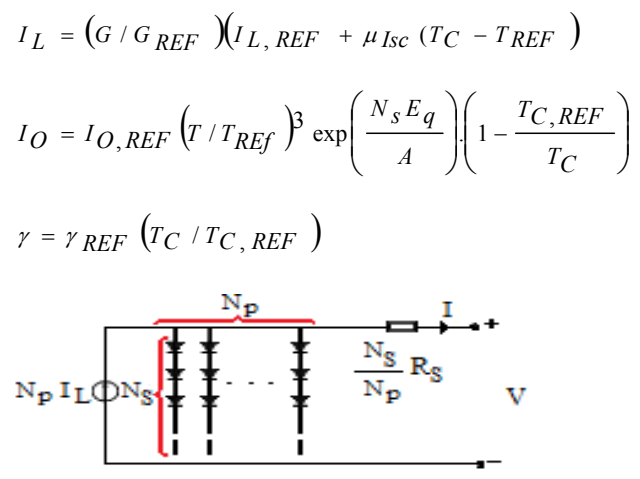

Fig. 3: Mathematic Model Of A PV Array

The parameters evaluated in this section are based on data input for a single module at some reference condition. To describe the I-V characteristic for the entire array that contains series and parallel modules as shown in fig.3, parameters need be scaled up in the following way:

$I_{L, t o t}=N_{p} I_{L}$

$I_{0, t o t}=N_{p} I_{0}$

$\gamma_{t o t}=N_{S} \gamma$

$R_{S, t o t}=\frac{N_{S}}{N_{P}} R_{S}$

Where, $N_{S}$ and $N_{P}$ are cell numbers of the series and parallel cells respectively.

Connecting cells in series will increase the output voltage, and connecting them in parallel will increase the output current, corresponding to the expression

$I_{\text {tot }}=N_{p} I$ 


\section{Journal of Theoretical and Applied Information Technology \\ $30^{\text {th }}$ November 2012. Vol. 45 No. 2}

(C) 2005 - 2012 JATIT \& LLS. All rights reserved.

जคิTี

ISSN: 1992-8645

www.jatit.org

E-ISSN: 1817-3195

$V_{\text {tot }}=N_{S} V$

All parameters of the model use the data in table 1.

Table 1: Parameters For PV Model

\begin{tabular}{|l|l|}
\hline \multicolumn{1}{|c|}{ Parameters } & \multicolumn{1}{c|}{ Values } \\
\hline $\begin{array}{l}\text { Nombre des cellules en série } \\
\text { Ns }\end{array}$ & 54 \\
\hline $\begin{array}{l}\text { Referenced solar irradiance } \\
G_{\text {ref }}\end{array}$ & $G=1000 \mathrm{~W} / \mathrm{m}^{2}$ \\
\hline $\begin{array}{l}\text { Referenced cell temperature } \\
T_{\text {ref }}\end{array}$ & $T=25{ }^{\circ} \mathrm{C}$, \\
\hline Imp & $7,6295 \mathrm{~A}$ \\
\hline Vmp & $26,8507 \mathrm{~V}$ \\
\hline Pmp & $204,8574 \mathrm{~W}$ \\
\hline Voc & $33,0978 \mathrm{~V}$ \\
\hline Isc & $8,1887 \mathrm{~A}$ \\
\hline KV & $-0,1230 \mathrm{~V} / \mathrm{K}$ \\
\hline KI & $0,0032 \mathrm{~A} / \mathrm{K}$ \\
\hline
\end{tabular}

With different temperatures and solar radiations, output characteristics of PV array are presented in fig.4 and fig.5.

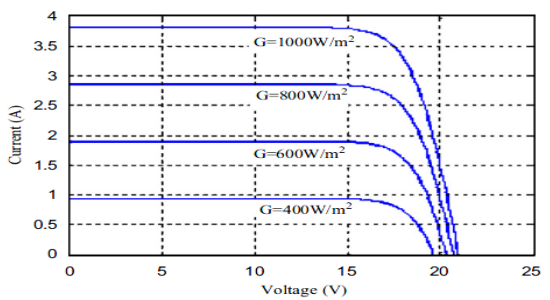

Fig. 4. Effect Of Irradiance On I-V Characteristics.

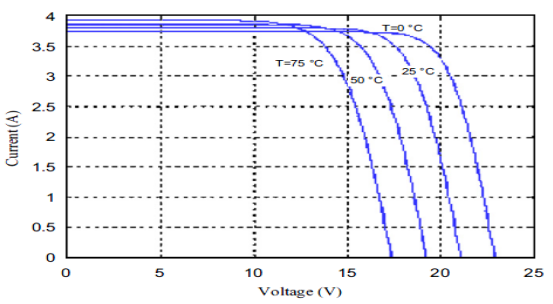

Fig. 5. Effect Of Temperature On I-V Characteristics.

As shown in fig.4 and 5, PV cell represents nonlinear voltage-current characteristics, and there is only one point that makes the PV generator generating its maximum power under different environmental conditions.

\subsection{Maximum Power Point Tracking}

In order to improve the efficiency of the PV generation system, PV array should be controlled to generate the maximum power at the particular environment conditions. Maximum Power Point Tracking (MPPT) aims at using some control algorithms to ensure the PV array to operate at the maximum power point.

At the maximum power point we have:

$\frac{\partial P}{\partial V}=V \frac{\partial I}{\partial V}+I=0$

With the current described by equation (6), the partial derivative of I with respect to $\mathrm{V}$ is:

$\frac{\partial I}{\partial V}=-I_{0} \exp \left(\frac{q\left(V+I R_{S}\right)}{k T_{C}, R E F} \gamma\right) \times \frac{q}{k T_{C, R E F}} \times\left(1+R_{S} \frac{\partial I}{\partial V}\right)$

An explicit expression for $\frac{\partial I}{\partial V}$ is obtained simply by rearranging equation (20). Back substitution of this explicit expression (20) and using $\mathrm{I}_{\mathrm{MP}}$ for I and $\mathrm{V}_{\mathrm{MP}}$ for $\mathrm{V}$ gives:

$I_{L}+I_{0} \exp \left(\frac{q\left(V_{M P}+I_{M P} R_{S}\right)}{k T_{C}, R E F \gamma}\right) \times$

$\left(1+\frac{\frac{q V_{M P}}{k T_{C, R E F} \gamma}}{1+\frac{q R_{S} I_{0}}{k T_{C, R E F} \gamma} \exp \left(\frac{q\left(V_{M P}+I_{M P} R_{S}\right)}{k T_{C, R E F} \gamma}\right)}\right)=0$

To eliminate $V_{M P}$ in equation (21), the general I-V equation (6) is used, with $\mathrm{I}_{\mathrm{MP}}$ substituted for I and $\mathrm{V}_{\mathrm{MP}}$ substituted for $\mathrm{V}$. Rearranging to solve for $V_{M P}$ gives

$V_{M P}=\frac{k T_{C, R E F} \gamma}{q} \ln \left(\frac{I_{L}-I_{M P}}{I_{0}}+1\right)-I_{M P} R_{S}$

An explicit expression for $I_{M P}$ is obtained by substituting equation (22) into equation (21):

$$
I_{M P}+\frac{\left(I_{M P}-I_{L}-I_{0}\right)\left[\ln \left(\frac{I_{L}-I_{M P}}{I_{0}}+1\right)-\frac{I_{M P} R_{S} q}{k T_{C, R E F} \gamma}\right]}{1+\left(I_{L}-I_{M P}+I_{0}\right) \frac{R_{S} q}{k T_{C, R E F^{\gamma}}}}=0
$$

Newton Raphson is applied to solve for $I_{M P}$ using an initial guess given by

$I_{M P, G U E S S}=\frac{G}{G_{R E F}} N P\left(I_{M P, R E F}+\mu_{I S C}\left(T_{C}-T_{C, R E F}\right)\right)$

Once $I_{M P}$ is found, $V_{M P}$ may be calculated using equation (24) and thus the current and voltage at the maximum power point is determined as a consequence the maximum power . 


\section{Journal of Theoretical and Applied Information Technology \\ $30^{\text {th }}$ November 2012. Vol. 45 No.2}

(C) 2005 - 2012 JATIT \& LLS. All rights reserved

ISSN: 1992-8645

www.jatit.org

E-ISSN: 1817-3195

\subsection{Boost Circuit And Its Control}

Since the output voltage of PV cell is low, the use of boost circuit will enable low-voltage PV array to be used, as a result, the total cost will be reduced. A capacitor is generally connected between PV array and the boost circuit, which is used to reduce high frequency harmonics. Figure 6 is the configuration of the boost circuit and its control system.

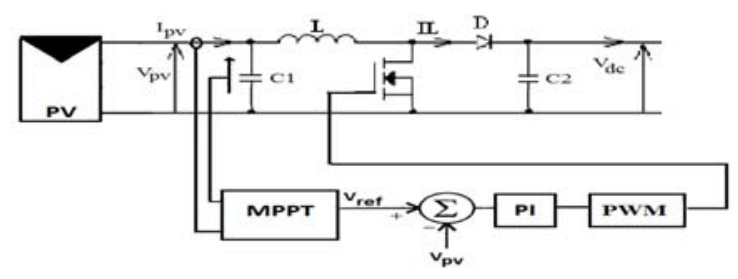

Fig.6. Boost Circuit And Its Control

The modeling of this converter depends on the analysis of the various sequences of operation which we will suppose of durations fixed by a control element $U$. There is two sequences of operation depending on the state of the switch $\mathrm{S}$, which we can represent each one by a differential equation $[7,8,9]$.

- When the switch is closed:

$$
\begin{gathered}
V_{p v}=L \frac{d I p v}{d t} \\
0=C \frac{d V_{d c}}{d t}+I d c
\end{gathered}
$$

- When the switch is open

$I_{p v}=C \frac{d V d c}{d t}+I_{d c}$

By supposing $U=1$, when the switch is closed and $\mathrm{U}=0$ for $\mathrm{S}$ opened, we can represent the converter by a single system of equations, that we describe as instantaneous model. We consider the perfect switches here.

$V_{p v}=L \frac{d I p v}{d t}+V_{d c}(1-U)$

$(1-U) I_{p v}=C \frac{d V d c}{d t}+I d c$

The instantaneous model reveals a nonlinear behavior of the converter by the existence of products between the control element $U$ and the state variables $\mathrm{Vdc}$ and Ipv. In addition it is advisable to announce that by replacing the variable $\mathrm{U}$ by its mean value over one switching period of $\mathrm{Td}=1 / \mathrm{fd}$, i.e. the duty cycle $\mathrm{D}(\mathrm{D}=\mathrm{Ton} / \mathrm{Td})$ we can obtain the model with the mean values:

$\frac{d I p v}{d t}=-(1-D) \frac{V_{d c}}{L}+\frac{V_{p v}}{L}$

(30)

$\frac{d V_{d c}}{d t}=(1-D) \frac{I p v}{C}-\frac{V_{d c}}{R C}$

(31)

PV array can be controlled to operate at the maximum power point by regulating the duty cycle $D$. The control scheme includes two levels. The control circuit aims to regulate the voltage using the reference voltage $V_{\text {ref }}$ calculated by MPPT algorithm and generate the control signals for the boost gate as illustrated in Fig. 6.

\section{CONTROL OF THE GRID-CONNECTED INVERTER}

PV array is connected to the ac grid via a common $\mathrm{DC} / \mathrm{AC}$ inverter. The inverter is used in current control method with PWM switching mechanism to make the inductance current track the sinusoidal reference current command closely and obtain a low THD injected current.

\subsection{Uncoupled Watt-Var Method}

In order to understand the principle of this method in the general case, we consider an inverter connected to the network, via a resistor $\mathrm{R}$ and the inductance $\mathrm{L}$ (which represent the simplified model of a transformer), as indicated on fig.7.

We have the following equation:

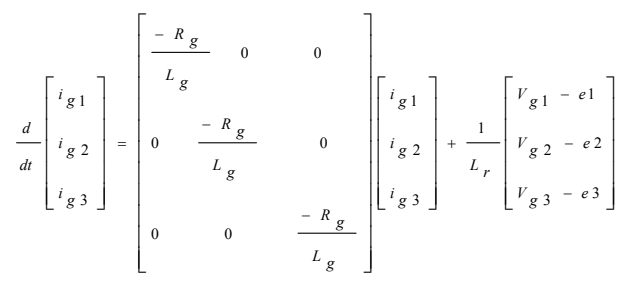

Where:

$\mathrm{Vg}$ and Ig represent the voltage and current of the grid. 


\section{Journal of Theoretical and Applied Information Technology \\ $30^{\text {th }}$ November 2012. Vol. 45 No. 2 \\ (C) 2005 - 2012 JATIT \& LLS. All rights reserved.}

ISSN: 1992-8645

www.jatit.org

E-ISSN: 1817-3195

$\mathrm{R}_{\mathrm{g}}, \mathrm{L}_{\mathrm{g}}$ resistance and inductance of the gird and $\mathrm{e}$ is the inverter voltage.

Applying abc to dq transformation of Park, the equation (32) is written in the following way: $\frac{d}{d t}\left[\begin{array}{c}i_{g d} \\ i_{g q}\end{array}\right]=\left[\begin{array}{cc}\frac{-R_{g}}{L_{g}} & \omega \\ -\omega & \frac{-R_{g}}{L_{g}}\end{array}\right]\left[\begin{array}{c}i_{g d} \\ i_{g q}\end{array}\right]+\frac{1}{L}\left[\begin{array}{c}V_{g d}-e_{d} \\ V_{g q}-e_{q}\end{array}\right]$

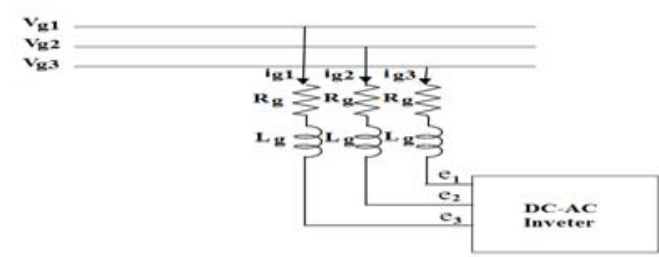

Fig.7: Diagram Of An Inverter Connected To The Grid

To know the advantages of the control method, the traditional uncoupled Watt-VAR algorithm is briefly presented.

The two new variables presented in (34), are the output variables of the control system which contains two PI controllers:

$$
\begin{aligned}
& X_{1}=\frac{1}{L_{g}}\left(V_{g d}-e_{d}\right) \\
& X_{2}=\frac{1}{L_{g}}\left(V_{g q}-e_{q}\right)
\end{aligned}
$$

The values of id, ref. and iq, ref. are the references of the active and reactive currents [10]:

$$
\begin{aligned}
& X_{1}=\left(K_{P}+\frac{K_{I}}{S}\left(I_{d, r e f}-i_{g d}\right)-\omega i_{g q}\right. \\
& X_{1}=\left(K_{P}+\frac{K_{I}}{S}\left(I_{q, \text { ref }}-i_{g q}\right)-\omega i_{g d}\right.
\end{aligned}
$$

Let's apply the Laplace transformation to the equation (33). Thus we transform the equations (34) and (35). We obtain the transfer functions

$$
F(S)=\frac{i_{g d}}{i_{d, r e f}}=\frac{i_{g q}}{i_{q, \text { ref }}}=\frac{K_{I}+S K_{P}}{K_{I}+S\left(\frac{R_{g}}{L_{g}}+K_{P}+S^{2}\right)}
$$

The control is optimal when both $\mathrm{K}_{\mathrm{P}}$ and $\mathrm{K}_{\mathrm{I}}$ are maximum [10].

The diagram of control by the method "uncoupled
Watt-VAR method" is represented on fig.8.

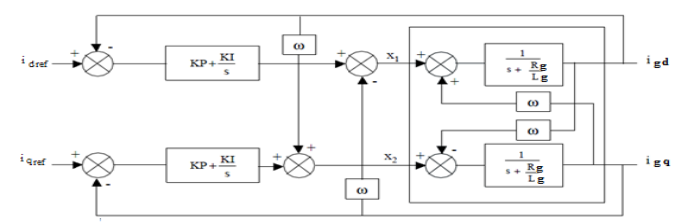

Fig.8: Diagram Block Of The Uncoupled Watt-VAR

\section{Method}

The total diagram of the identification of the references and regulation of the current for this method is shown on fig. 9 where the regulators are those of fig. 8 .

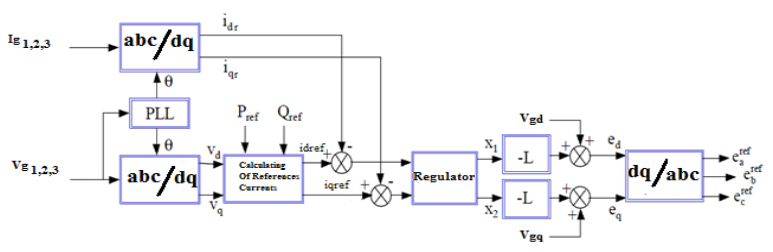

Fig.9: Total Diagram Of Control By The Uncoupled

Watt-VAR Method

The goal of this control method is to impose the values of the active and reactive powers injected into electrical grid.

The powers and the voltage at the connection point are calculated in the dq reference frame [11]:

$$
\begin{aligned}
& P_{r e f}=\frac{3}{2}\left(v_{d r} i_{d r}+v_{q r} i_{q r}\right) \\
& Q_{r e f}=\frac{3}{2}\left(v_{d r} i_{q r}+v_{q r} i_{d r}\right)
\end{aligned}
$$

Where $\mathrm{P}_{\text {ref }}$ and $\mathrm{Q}_{\mathrm{ref}}$ are the reference powers.

We can deduce the current in the dq frame as follows:

$i_{d, r e f}=\frac{2}{3} \frac{\left(P_{g} V_{g d}+Q_{g} V_{g q}\right)}{V_{g d}^{2}+V_{g q}^{2}}$
$i_{q, r e f}=\frac{2}{3} \frac{\left(P_{g} V_{g q}+Q_{g} v_{g d}\right)}{V_{g d}^{2}+V_{g q}^{2}}$

$\mathrm{V}_{\mathrm{gd}}$ and $\mathrm{V}_{\mathrm{gq}}$ are the direct and quadrature components of the voltage at the connection point in the dq reference frame. 


\section{Journal of Theoretical and Applied Information Technology \\ $30^{\text {th }}$ November 2012. Vol. 45 No. 2 \\ (C) 2005 - 2012 JATIT \& LLS. All rights reserved.}

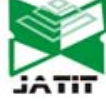

ISSN: 1992-8645

www.jatit.org

E-ISSN: 1817-3195

$\mathrm{I}_{\mathrm{d}, \mathrm{ref} .}$ and $\mathrm{I}_{\mathrm{q}, \mathrm{ref}}$ are the direct and quadrature current components injected into the grid.

These currents depend on the power requested and the voltages measured at the point of connection. This voltage is transformed in the dq frame before the calculation of the currents as explained by fig. 9.

The role of the phase locked loop is to provide the rotation frequency, direct and quadrature voltage components at the point of common coupling (PCC) by resolving the grid voltage $a b c$ components.

Multiple control blocks of the PV system rely on this information to regulate their output command signals. As stated earlier, the PLL computes the rotation frequency of the grid voltage vector by first transforming it to the $d q$ frame, and then force the quadrature component of the voltage to zero to eliminate cross coupling in the active and reactive power terms [12]. A proportional-integral controller is used to perform this task. The proportional $(\mathrm{Kp})$ and integral $(\mathrm{Ki})$ gains of the controller were set through an iterative process to achieve a fast settling time.

The components of the current are compared with its references. The differences between them passed through regulators, which give the components of the reference voltage in the $\mathrm{dq}$ reference. While passing by the reverse transformation dq to abc, we obtain the references of the PWM signals for the inverter.

\subsection{BUS VOLTAGE CONTROLLER}

The regulation of this voltage is carried out when absorbing or providing the active power to the grid. The correction of this voltage must be done by the addition of an active fundamental current into the reference currents.

Based on a difference between $\left(\mathrm{U}_{\text {dcref }}^{2}\right)$ and $\left(\mathrm{U}_{\mathrm{dc}}^{2}\right)$, the power (Pref) on the regulator output side is added to the fluctuating active power and gives place to an active fundamental current thus regulating the dc bus voltage.

In order to obtain the (Pref) signal, we have the choice between a proportional regulator and a proportional integral regulator. This last one is often used and gives better results in preventing the static errors.

The schematic diagram of calculating and of regulating of the Dc bus voltage standard is given by the figure 10 .

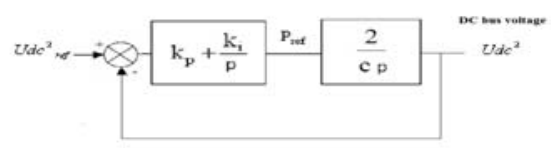

Fig.10: Schematic Diagram Of The DC Link Controller.

\section{SIMULATION RESULTS}

Based on the above models and control methods, two simulation cases are studied:

a. steady operation, when there is no change in atmospheric conditions;

b. changes of solar irradiance and the dc bus control will stabilize the inverter input voltage;

\subsection{Steady Operation}

When the system is in steady state, solar irradiance is $1000 \mathrm{~W} / \mathrm{m}^{2}$, and temperature is $298 \mathrm{~K}$.

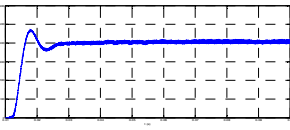

(A): PV Generator Voltage

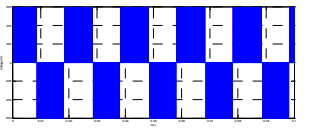

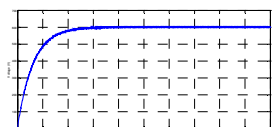

(B): DC Bus Voltage

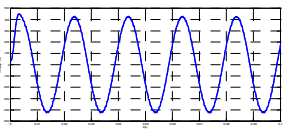

(C) : Phase To Phase Inverter's (D): Phase To Phase Inverter's Voltage Before Filtering Voltage After Filtering
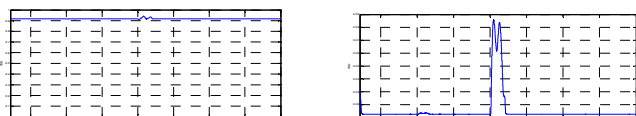

(E): Thd In Voltage Before

Filtering

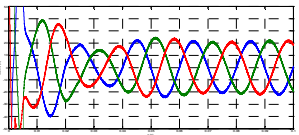

(G): Inverter Output Currents
(F) : Thd In Voltage After Filtering

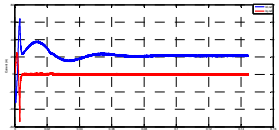

(H): Id,Ref And Iq,Ref Current 


\section{Journal of Theoretical and Applied Information Technology \\ $30^{\text {th }}$ November 2012. Vol. 45 No. 2 \\ (c) 2005 - 2012 JATIT \& LLS. All rights reserved.}

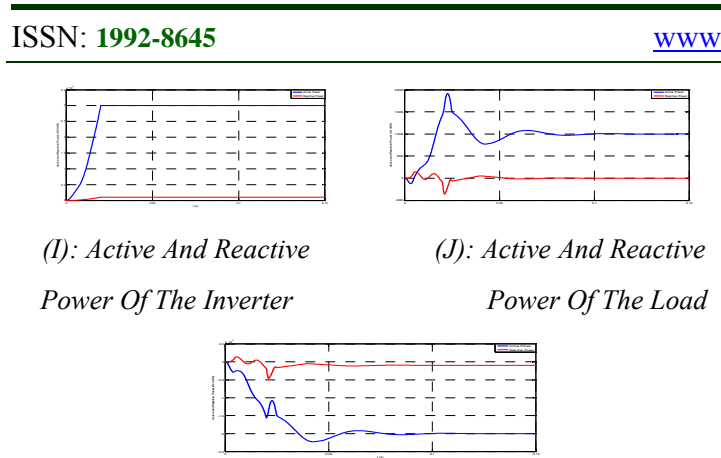

(K): Active And Reactive Of The Grid

Fig.11: Simulation Results Of The System In Steady State

From figures (a)-(d), at this operation situation,. In steady state, the operation point of PV array is just its maximum power point. The power requested by the load is $30 \mathrm{KW}$ and $1 \mathrm{KVAR}$. Since the PV array generate only an active power of $10 \mathrm{KW}$ and no reactive power (because the regulation system as shown in fig (1) has two inputs Id,ref and Iq,ref that is the image of reactive power and obviously its value is set to Zero) the rest of the requested power comes from the grid as illustred in figures ((i),(j),(k)., The voltage at dc bus is regulated to be $600 \mathrm{~V}$ the currents of inverter have sinusoidal forms and its maximum is $20 \mathrm{~A}$.

Figures ((c), (d), (e), (f)) represents the voltage of the inverter before and after filtering it seems that the filter has improve the THD from about $92 \%$ into less than $1.2 \%$.

\subsection{Changes Of Solar Irradiance}

Assuming solar irradiance changes: during 0 to $0.1 \mathrm{~s}$, solar irradiance is $1000 \mathrm{~W} / \mathrm{m}^{2}$; during $0.1 \mathrm{~s}$ to $0.2 \mathrm{~s}$, solar irradiance is $500 \mathrm{~W} / \mathrm{m}^{2}$; during $0.2 \mathrm{~s}$ to $0.3 \mathrm{~s}$, solar irradiance returns to $1000 \mathrm{~W} / \mathrm{m}^{2}$. Due to this change we have droop in both $\mathrm{pV}$ voltage and $\mathrm{DC}$ bus voltage as shown in figure 12 .

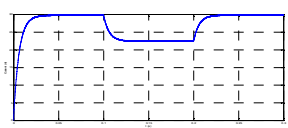

(L): Photovoltaic Current

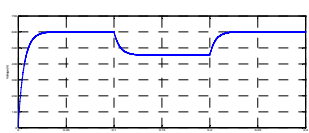

(M): DC Bus Voltage
Fig.12: Simulation Results Of The PV System When Solar Irradiance Changes From 1000 W/M ${ }^{2}$ To $600 \mathrm{~W} / \mathrm{M}^{2}$ And Then To $1000 \mathrm{~W} / \mathrm{M}^{2}$ Again
When solar irradiance is $600 \mathrm{~W} / \mathrm{m}^{2}$, DC bus voltage is less than $600 \mathrm{~V}$ so the dc bus regulator must act to maintain the DC bus voltage constant (at $600 \mathrm{~V}$ ). In figure 13 the DC bus voltage controller has insure a constant voltage that make PV system able to feed the inverter and the load,

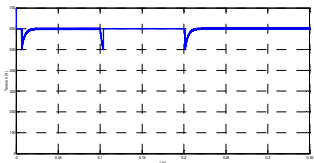

Fig. 13 :The Effect Of DC Controller On The DC Bus

Voltage

\section{CONCLUSIONS}

In this paper, a grid-connected photovoltaic generation system is studied. In order to convert the solar energy efficiently, the maximum power point of the PV array should be tracked to ensure the PV array provide most power to both grid and the load. When solar irradiance or temperature fluctuates, PV generation will change as a result. The controller must act to maintain the DC bus voltage constant as possible and improve the stability of the whole system. the simulation results presented in this paper validate the component models and the chosen control scheme.

\section{REFERENCES}

[1] M.G. SIMOES,. FRANCE SCHETTI,N.N.« Arisc-Microcontroller Based Photovoltaic System for Illumination Applications, Proceeding of IEEE Applied Power Electronics Conference and Exposition 15 (2000).

[2] CHENNI, R.-MAKHLOUF, M. et al: «Detailed Modelling Method for Photovoltaic Cell, Energy 32 (2007), 1724-1730.

[3] Townsend, Timothy U. «A Method for Estimating the Long-Term Performance of Direct- Coupled Photovoltaic Systems». M. S. Thesis. Solar Energy Laboratory, University of Wisconsin, Madison: 1989. 
ISSN: 1992-8645

www.jatit.org

E-ISSN: 1817-3195

[4] Eckstein, Jurgen Helmut, «Detailed Modeling of Photovoltaic Components», M. S. Thesis Solar Energy Laboratory, University of Wisconsin, Madison: 1990.

[5] F.Bryan, «Simulation of grid-tied building integrated photovoltaic systems» M. S. Thesis Solar Energy Laboratory, University of Wisconsin, Madison: 1998.

[7] M.Fadel, «Lois de commande pour une alimentation $\mathrm{AC} / \mathrm{DC}$ à absorption de courant sinusoïdal» 3EI 2000.

[8] J.P. Ferrieux, F. Forest, "Alimentations à découpage Convertisseurs à résonance. Principes-composants, modélisation», Dunod 3e édition - 2001 - ISBN 2-10-004137-1.

[9] J.Lachaize, M.Fadel, S.Caux, P.Shott, L.Nicod, «Modelling and Control of a fuel cell system for electrical rail transport », EPE 2003 Toulouse, France - Sept 2-4.

[10] I. Papic, P. Zunko, D. Povh and M. Weinhold, «Basic Control of Unified Power Flow Controller », IEEE Trans. On Power Systems, vol. 12, No. 4, pp. 1734-1739, November 1997.

[11] G.RAMI, « Contrôle de tension auto adaptatif pour des productions décentralisées d'énergies Connectées au réseau électrique de distribution », Thèse de doctorat DE L'INP Grenoble

[12] Kroutikova, N.; Hernandez-Aramburo, C.A.; Green, T.C, «State-space model of grid-connected inverters under current control mode ", Electric Power Applications, IET , vol.1, no.3, pp.329-338, May 2007, 1677-1688, 2008. 